CEZARY W. DOMAŃSKI ${ }^{1}$

Instytut Psychologii

Uniwersytet Marii Curie-Skłodowskiej

Studia Psychologica

UKSW

16(1) 2016 s. 23-33

\title{
ZNACZĄCY EPIZOD. VIKTOR TAUSK W LUBLINIE I JEGO BADANIA NAD PSYCHOZAMI WOJENNYMI
}

\section{STRESZCZENIE}

Viktor Tausk, austriacki prawnik, literat i lekarz, związał się z ruchem psychoanalitycznym w pierwszej dekadzie XX wieku. Jesienią 1909 roku został członkiem Wiedeńskiego Towarzystwa Psychoanalitycznego. Uczestniczył w spotkaniach środowych z Sigmundem Freudem i innymi pionierami psychoanalizy. Po wybuchu I wojny światowej został zmobilizowany w stopniu oficerskim. Służył jako lekarz psychiatra w armii austro-węgierskiej. Przez dziewięć miesięcy stacjonował w Lublinie. Wtedy to właśnie zebrał i przeanalizował materiał, który stanowił podstawę dwóch ważnych opracowań naukowych w jego dorobku: jedno z nich dotyczyło tak zwanej psychozy wojennej, drugie zaś - psychologii dezerterów.

Słowa kluczowe: Viktor Tausk, psychoanaliza, psychoza wojenna, nerwica wojenna, psychologia dezerterów, Lublin

\section{A SIgNificant EPISODE. ViKTOR TAUSK IN LUBLIN AND HIS RESEARCh ON WAR PSYCHOSES}

\section{ABSTRACT}

Viktor Tausk, an Austrian lawyer, a writer and a doctor, had ties to the psychoanalytic movement in the first decade of the $20^{\text {th }}$ century. In fall of 1909 he became member of the Vienna Psychoanalytic Society. He participated in the Wednesday meetings with Sigmund Freud and other pioneers of psychoanalysis. He served as a physician-psychiatrist in the Austro-Hungarian army. He was stationed in Lublin for a period of nine months. It was there that he gathered and analyzed the material, that formed the basis for his two important works: one of them concerned the so called 'war psychosis', the other the psychology of deserters.

Keywords: Viktor Tausk, psychoanalysis, war psychosis, war neurosis, psychology of deserters, Lublin

$1 \quad$ Adres do korespondencji: cezary.domanski@poczta.umcs.lublin.pl. 


\section{WPROWADZENIE}

Jednym $\mathrm{z}$ bardziej nietuzinkowych uczestników wczesnej fazy rozwoju ruchu psychoanalitycznego był Viktor Tausk (1879-1919) ${ }^{2}$. Ten pochodzący ze słowackiego miasteczka Żylin (niem. Sillein, węg. Zsolna) najstarszy syn żydowskiego nauczyciela i dziennikarza miał już bogate doświadczenie życiowe, gdy około roku 1909 zaczął regularnie spotykać się z Sigmundem Freudem i skupionymi wokół niego w Towarzystwie Środowym entuzjastami nowej teorii psyche (Bronner, 2008). Szczególną cechą wczesnej biografii Tauska była częsta zmiana miejsca zamieszkania. Naukę gimnazjalną rozpoczął w Zagrzebiu, kontynuował w Sarajewie, później ze względów zdrowotnych kończył ją w Rijece i Dubrowniku, a świadectwo maturalne uzyskał w roku 1897 w Varaždinie ${ }^{3}$. Immatrykulował się na Wydziale Prawa Uniwersytetu Wiedeńskiego, aby wkrótce przenieść się do Berlina, gdzie wprawiał się w zawodzie dziennikarza i pisarza. W roku 1900 zawarł związek małżeński i po dokończeniu studiów prawniczych odbywał staż adwokacki w Sarajewie. Zatrudnił się w kancelarii radcy prawnego w Mostarze. Stamtąd przeprowadził się do Wiednia, a następnie znów wyjechał do Berlina, gdzie utrzymywał się ze współpracy z lokalnymi dziennikami. Napisał wtedy między innymi dramat Halbdunkel oraz zaprzyjaźnił się ze znaczącymi osobami z berlińskiego świata kultury: Martinem Buberem i Frankiem Wedekindem. W roku 1907, po krótkim pobycie w jednym $\mathrm{z}$ nadreńskich sanatoriów powrócił do Wiednia. Zapisał się na studia medyczne w Uniwersytecie Wiedeńskim, które ukończył z dyplomem doktora w styczniu 1914 roku. Okres tych studiów to czas intensywnych kontaktów z Freudem i członkami Wiedeńskiego Towarzystwa Psychoanalitycznego, których nie zaprzestał mimo powołania do wojska, jakie otrzymał po wybuchu I wojny światowej. Od roku 1915 pełnił funkcję asystenta lekarza „pospolitego ruszenia", inaczej: obrony krajowej (landszturmu). Stacjonował w różnych miejscowościach Austro-Węgier i byłego Królestwa Polskiego. W roku 1918 uczestniczył w V Międzynarodowym Kongresie Psychoanalitycznym w Budapeszcie. W pierwszych miesiącach powojennych Tausk przeżył silny kryzys psychiczny. W jego wyniku na początku lipca 1919 roku popełnił w Wiedniu samobójstwo. Został pochowany w odległej od głównego wejścia kwaterze na wiedeńskim Cmentarzu Centralnym ${ }^{4}$.

2 Podstawowe fakty biograficzne podane we Wprowadzeniu pochodzą z dwóch biografii Viktora Tauska: Roazen, 1973 oraz Eissler, 1983.

3 Wartościowym przyczynkiem do biografii Tauska jest artykuł P. Brajšy (1981) na temat epizodu varaždinskiego.

4 Malowniczo opleciony bluszczem nagrobek z białego marmuru przeznaczony był do likwidacji w roku 2016. Koncesja została przedłużona do 2026 roku. 


\section{WOJENNa ODYSEJa TaUsKa}

Pomimo że lata I wojny światowej były w życiu Viktora Tauska ważnym okresem, są one w jego dwóch biografiach scharakteryzowane najsłabiej (Roazen, 1973; Eissler, 1983) ${ }^{5}$. W pokoleniu Tauska liczna rzesza obywateli Austro-Węgier mających już swoje miejsce w świecie kultury i nauki została wyrwana $\mathrm{z}$ własnych środowisk i postawiona wobec koszmaru wojny. Wspomnieć można choćby dwie ważne postacie: Georga Trakla (1887-1914), znakomitego poetę ekspresjonistę oraz Ottona Rosenfelda (znanego jako Otto Rank, 1884-1939), psychoanalityka i dysydenta freudyzmu. Obaj zostali zmobilizowani i brali udział w działaniach frontowych. Ich losy odzwierciedlają skrajne postawy, będące w pewnym sensie następstwem okrucieństwa wojny, z którym musieli się zmierzyć. Pierwszy z nich odebrał sobie życie, drugi zaś nie potrafił sobie radzić z problemami codzienności. Biografia Tauska również jest naznaczona przeżyciami z okresu I wojny światowej.

Służbę wojskową rozpoczął Tausk 2 sierpnia 1915 roku. Został skierowany do Rzeszowa jako pomocnik lekarza wojskowego w tamtejszym szpitalu garnizonowym. Mniej więcej dwa miesiące później, gdy część guberni wołyńskiej została zajęta przez armię austro-węgierską, przeniesiono go do Kowla (Tréhel, 2006). Od 5 grudnia 1915 roku do sierpnia 1916 roku stacjonował w Lublinie. Od 10 sierpnia do grudnia tegoż roku przebywał w Grimmenstein (Dolna Austria). Następnie przez kilkanaście miesięcy pracował w szpitalu w Belgradzie ${ }^{6}$ (Tréhel, 2006).

Trudno jest odtworzyć szczegóły dziewięciomiesięcznego pobytu Viktora Tauska w Lublinie. W prasie lubelskiej nie udało się odnaleźć żadnych wzmianek, gazety wiedeńskie również nie odnotowały śladu wydarzeń związanych $\mathrm{z}$ jego stacjonowaniem w mieście nad Bystrzycą. Warto zauważyć, że Tausk został przeniesiony do Lublina kilka miesięcy po tym, gdy zainstalowały się tu władze austro-węgierskie. Nie wiadomo, czy miał na to wpływ fakt, że jednym z pierwszych oficerów armii austro-węgierskiej, który latem 1915 roku na czele oddziału wkroczył do opuszczonego przez Rosjan miasta, był syn Sigmunda Freuda, Martin (zob. Domański, 2009). Mógł przedstawić Lublin rodzinie i znajomym jako stosunkowo spokojne i położone $\mathrm{z}$ dala od działań wojennych miasto, w którym da się mieszkać w znośnych warunkach. W każdym razie Tausk znalazł się w dość komfortowej sytuacji, ponieważ służba wojskowa w Lublinie

5 Brak analitycznej pracy na temat wojennych kolei losu Tauska skutkuje wprowadzaniem do literatury przedmiotu błędnych informacji. Na przykład chorwacka filozofka Tatjana Jukić przeniosła w swoim artykule miejsce wojennej praktyki austriackiego psychoanalityka do... Lwowa. Pisze ona: „a već će 1915. biti upućen u L’vov [sic!'] kao vojni psihijatar; uskoro objavljuje rad o simptomatologiji takozvane ratne psihoze” (Jukić, 2011, s. 232).

6 Był to K. u K. Reservespital „Brčko“ [zob. Vjelković, S. (2012). Život i rad Vojne bolnice u Beogradu za vreme Velikog rata (1914-1918). Pobrane z: http://www.rastko.rs/rastko/ delo/14674]. 
nie narażała go na stres działań frontowych. Jednocześnie na ulicach miasta dość powszechnie rozbrzmiewał język niemiecki. Właśnie tu 1 października 1915 roku władze austro-węgierskie zorganizowały Generalne Gubernatorstwo Wojskowe (Militärgeneralgouvernement in Lublin). W mieście panowała wyjątkowa atmosfera. Jeden ze świadków epoki pisał nawet:

Nadzwyczaj miły był okres okupacji austriackiej w Lublinie. Nigdy przedtem ani potem Lublin nie miał takiego życia jak wtedy. Miasto było centralą okupacji austriackiej, siedzibą władz Generalnej Guberni z generałem gubernatorem na czele. $Z$ początku był nim jakiś Austriak [...], a następnie generał Stanisław Szeptycki, bo cesarz Karol [Karol I Habsburg] życzył sobie by nim został Polak [...]. Całe ziemiaństwo z Lubelszczyzny zjechało podczas okupacji do miasta. Wielu urzędników Polaków z Małopolski i Wiednia przyjechało z rodzinami. Wszyscy prowadzili tak zwane otwarte domy, bywali u innych i przyjmowali u siebie. (Doliński, 1992, s. 143-144).

Przychylny stosunek miejscowych obywateli do administracji i armii austro-węgierskiej mógł mieć wpływ na niejaką stabilizację Tauska, który zatrzymał się w mieście na dłużej.

Tausk pełnił funkcję lekarza-asystenta obrony krajowej (Landsturm Assist.Arzt) i został przydzielony do Szpitala Rezerwy numer $1 \mathrm{w}$ ramach 4 Armii $^{7}$. Trzeba wyjaśnić, że w latach 1915-1916 Lublin był centrum szpitalnym dla wojsk austro-węgierskich i niemieckich; zwożono tu rannych z terenu działań wojennych na Polesiu i Wołyniu. Budynki zajęte pod infrastrukturę medyczną znajdowały się w różnych punktach miasta. W sumie znajdowały się tu cztery oddziały szpitalne 4 Armii (1/IV, 4/IV, 7/IV i 10/IV ${ }^{8}$; Konefał, 1999). Trudno jednoznacznie stwierdzić, gdzie mieszkał i ordynował Tausk, choć, jak się wydaje, mogło to być w koszarach wojskowych przy Szosie Warszawskiej (obecnie Aleje Racławickie). Nie jest dziś możliwe odtworzenie szczegółów pobytu Tauska w Lublinie, zwłaszcza dotyczących jego życia prywatnego (kontaktów, spędzania czasu wolnego itp.). Jeśli chodzi o jego obowiązki służbowe, to oprócz doraźnych konsultacji był także biegłym psychiatrą przy sądzie wojskowym. Podobno prowadził również praktykę prywatną (Roazen, 1973). Praca w garnizonie była dość wyczerpująca, zaczynała się o godzinie 8 rano i trwała do 7 wieczorem, o czym pisał w jednym $z$ listów wysłanych wiosną 1916 roku do byłej żony. Jak twierdził po latach jego syn, Tausk uratował od śmierci kilku żołnierzy, którzy

7 Zob. np. K. und k. 4. Armee-Kommando (Qu.-Abt.), Armee-Kommando-Befehl Qu.-Nr. 43, s. 1 (dokument przechowywany w zbiorach Centralnego Archiwum Wojskowego, Warszawa-Rembertów).

8 Warto dodać, że wiosną 1916 roku w Lublinie otwarto w budynku seminarium duchownego szpital legionowy (zob. Szpital dla Legionistów Polskich w Lublinie, „Ziemia Lubelska”, nr 186 z dn. 16.04.1916, s. 3). 
odmówili wykonania rozkazów; wykorzystywał argumenty natury psychologicznej w opinii popierającej ułaskawienie (jeden $\mathrm{z}$ takich ocalonych miał później w domu portret Tauska; Roazen, 1973).

Jedyne wspomnienie z tego okresu, do którego udało się dotrzeć, dotyczy przypadkowego spotkania, opisanego przez Edoarda Weissa (1889-1970), psychoanalityka pochodzącego z Triestu. Po latach relacjonował on:

Gdy wybuchła wojna w 1914 roku, zostałem powołany do armii austriackiej i nie widziałem się z Viktorem Tauskiem aż do jesieni 1916. Wtedy to miałem służbę w pociągu szpitalnym, jadącym $\mathrm{z}$ frontu rosyjskiego do austriackiego szpitala wojskowego w Lublinie. Podczas wyładowywania pacjentów spotkałem Tauska w mundurze kapitana korpusu medycznego. Kiedy mieliśmy okazję porozmawiać, byłem zszokowany jego stanem głębokiej depresji. Był bardzo zmartwiony sytuacją światową i przekonany, że państwa centralne nie mogą wygrać wojny. Mówił, że Wiedeń stanie się stolicą okrojonego, podzielonego państwa, w którym psychoanalityk nie będzie miał zbyt wiele okazji, by zarobić na życie. Opowiadał również o nieszczęśliwych doświadczeniach osobistych. Kobieta, którą kochał, z którą był zaręczony, zdradziła go z innym mężczyzną. Twierdził, że inni nasi znajomi są także zdradzani przez swoje żony. Miał pesymistyczny obraz wszystkiego. Starałem się go zachęcić, by zrozumiał, że osoba w takim stanie depresji potrzebuje silnego wsparcia moralnego, ale byłem zbyt młody, aby pełnić rolę opiekuna Tauska. (Weiss, 1991, s. 11; tłum. własne)

Ze świadectwa Weissa wynika, że Tausk zdawał sobie sprawę z konsekwencji wojny; być może na podstawie rozmów $\mathrm{z}$ oficerami różnych narodowości służących w armii austro-węgierskiej wywnioskował, jak silne są ruchy narodowościowe i że zbliża się kres wielkiej monarchii. Nie bez znaczenia były nastroje panujące w Lublinie, choćby u przebywających tu legionistów. Trudno jest natomiast potwierdzić, że jego doświadczenie osobiste związane z niefortunnymi zaręczynami opierało się o jakąś znajomość z kobietą poznaną w Lublinie, choć zarówno Roazen (1973), jak i Eissler (1983) sugerują, że narzeczona zdradziła go $\mathrm{z}$ pacjentem leczonym przez niego właśnie tutaj.

Ze względu na chorobę płuc Tausk opuścił Lublin w sierpniu 1916 roku. Do grudnia tegoż roku kurował się w sanatorium w Grimmenstein (Dolna Austria). Być może powracał w tym czasie na krótko do Lublina, skoro jesienią Weiss spotkał go tu na stacji kolejowej. Może też zaszła jakaś pomyłka i spotkanie to nastąpiło na przełomie lipca i sierpnia. Po opuszczeniu sanatorium aż do końca wojny Tausk pracował jako neurolog wojskowy w Belgradzie. Tam na krótko związał się z serbską arystokratką Kosą Lazarević. Został odznaczony Orderem Franciszka Józefa' ${ }^{9}$ Po zdemobilizowaniu, w listopadzie 1918 roku rozpoczął

9 Zob. Aus dem Verordnungsblatt Nr. 119 für das k. u. k. Heer, „Neue Freie Presse”, 9.07.1916, nr 18635, s. 34 . 
prywatną praktykę w Wiedniu. Próbował dostać się na analizę do Freuda, lecz ten odmówił mu, kierując go do Heleny Deutsch. W rezultacie był jej pierwszym pacjentem; analizowała go przez trzy miesiące w roku 1919 (Roazen, 2001).

\section{TAUSK JAKO PSYCHIATRA WOJSKOWY}

Interesująco przedstawiała się działalność naukowa Viktora Tauska w latach 1914-1918. Była ona niewątpliwie wynikiem nagłej zmiany w jego życiorysie. Od stycznia 1914 roku do końca marca 1915 roku Tausk uczestniczył (z jedną absencją, w styczniu $1915 \mathrm{roku}$ ) we wszystkich środowych posiedzeniach Wiedeńskiego Towarzystwa Psychoanalitycznego (WPV) ${ }^{10}$. Nie było to jedyne miejsce jego aktywności, z czego nie zdawali sobie sprawy historycy psychoanalizy. Brał udział także w zebraniach innych grup naukowych, często jako czynny uczestnik. Na przykład na posiedzeniu wiedeńskiego Towarzystwa Psychiatrii i Neurologii (Verein für Psychiatrie und Neurologie) 6 czerwca 1915 roku (a więc krótko przed powołaniem do wojska) wygłosił referat Psychoanalytische Bemerkungen zum Inhalt des alkoholischen Beschäftigungsdelirs ${ }^{11}$. W okresie, gdy stacjonował w Lublinie, nazwisko Tauska nie pojawia się w protokołach WPV, z jednym ciekawym wyjątkiem. Otóż 7 czerwca 1916 roku wystąpił w Wiedniu na spotkaniu środowym z Freudem, aby zreferować temat Psychoanalytische Kriegserfahrungen. W ostatnich miesiącach tegoż roku (od października do połowy grudnia) znów uczestniczył w posiedzeniach WPV; jak się wydaje, pobyt sanatoryjny ułatwiał częste wyjazdy do stolicy monarchii. W roku następnym (1917) Tausk ponownie ani razu nie brał udziału w spotkaniach WPV, ponieważ wtedy stacjonował w Belgradzie.

Jakie wnioski można wyciągnąć z powyższych faktów? Po pierwsze, mimo podjęcia nowych, odpowiedzialnych obowiązków Viktor Tausk nie porzucił pracy naukowej. Wręcz przeciwnie, zyskał nowe możliwości obserwacji, co potrafił twórczo wykorzystać. Po drugie, jako zwolennik metod Freuda przejął również jego sposób pracy, na przykład referowanie i omawianie raportów z badań na zebraniach naukowych, przed ich opublikowaniem. Intrygującym i na razie trudnym do zweryfikowania epizodem z pobytu Tauska w Lublinie jest jego uczestnictwo w drugiej konferencji oficerów medycznych, która jakoby miała tu miejsce 19 stycznia 1916 roku. Zgodnie z przypisem, który dał do artykułu opublikowanego na łamach „Wiener Medizinische Wochenschrift”, to właśnie na tym spotkaniu przedstawił swoją pracę Diagnostische Erörtungen auf Grund der Zustandsbilder der sogennanten Kriegspsychosen (tłum. angielskie zob. w: Tausk, 1991). O seminarium tym źródła milczą; bezowocne okazały się poszukiwania w prasie lubelskiej i wiedeńskiej. Co ciekawe, materiał zebrany w czasie

10 Dokumentacja dostępna jest m.in. na stronie http://www.psyalpha.net/.

11 Zob. Vereinsnachrichten. „Neue Freie Presse”, 6.06.1915, 18244, s. 14. 
pobytu w Lublinie wykorzystał także w pracy Zur Psychologie des Deserteurs (tłum. angielskie zob. w: Tausk, 1991), referowanej przez niego 3 marca 1917 roku podczas dziewiątej konferencji oficerów medycznych w Belgradzie.

Warto w paru zdaniach przybliżyć istotę tych prac. Jak twierdził Tausk, w ciągu siedmiu i pół miesiąca służby wojskowej zbadał około tysiąca pięciuset pacjentów, w większości żołnierzy skierowanych na obserwację prosto $\mathrm{z}$ frontu. W tej grupie zdiagnozował tylko kilka przypadków typowej, „czystej” paranoi. Dość często rozpoznawał natomiast „melancholię”, niekiedy powiązaną z próbami samobójczymi. Miała ona zazwyczaj formę nieproduktywną, charakteryzującą się stuporem. W około jednej trzeciej przypadków towarzyszył jej lęk. Na podstawie tego rodzaju obserwacji w pracy Diagnostische Erörtungen auf Grund der Zustandsbilder der sogennanten Kriegspsychosen Tausk sugeruje, że odkrył nową jednostkę chorobową, którą nazwał psychozą wojenną. W nieco późniejszym tekście Zur Psychologie des Deserteurs zawarł natomiast opis studium przypadku młodego, pochodzącego ze wsi żołnierza, którego dezercja z wojska była wynikiem beznadziejnej sytuacji życiowej i braku wglądu w sytuację, w której znalazł się wbrew własnej woli. Najciekawszym wywodem w tym artykule jest jednak charakterystyka dezerterów oparta na analizie różnorakich przyczyn dezercji (Tausk wyróżnił siedem typów dezercji). Były wśród nich: dezercja jako odzwierciedlenie relacji między synem i ojcem, forma spełnienia dawnego pragnienia wydostania się spod władzy rodziców, dezercja jako ucieczka przed karą za przestępstwo, będąca efektem przeciążenia z powodu obowiązków, jakie wynikają ze służby wojskowej, spowodowana neurotyzmem w czystej postaci, którego skutkiem są lęk i obsesyjne idee (do tej kategorii należą też ambicje udaremnione przez pobór do wojska), lub motywowana tęsknotą za domem. Powodem dezercji mogą być także motywy polityczne oraz (jak to ujął Tausk) „brak zainteresowania celem obecnej wojny lub sprzeciw wobec niej” (1916/1991b, s. 161). W rozprawie na temat psychologii dezerterów zwracają uwagę te fragmenty, w których austriacki psychoanalityk odnosi się do kodeksu karnego i konsekwencji dezercji. Z punktu widzenia prawa akt dezercji jest zawsze czynem świadomym, podczas gdy Tausk dostrzegał u jego podstaw działanie wielu nieuświadamianych sobie przez dezertera przesłanek. Tekst kończy on dość szczególnym wnioskiem:

W tej wojnie uczestniczy grupa ludzi, którzy, podobnie jak dzieci, nie mogą się wyrzec zaspokojenia swoich pragnień [...] Chcą uniknąć cierpień nie własnym kosztem, jako dezerterzy, ale kosztem społeczeństwa. Oni nie są aspołeczni lecz antyspołeczni. Nie uhonorujemy ich nazywając dezerterami. Są to spekulanci wojny (war profiteers). (1916/1991b, s. 164; tłum. C.D.) 


\section{REFLEKSJE KOŃCOWE}

Prawie ćwierć wieku temu amerykański historyk psychoanalizy Paul Roazen wydał antologię zawierającą przekłady 12 artykułów Viktora Tauska na język angielski (Tausk, 1991). Znalazły się w niej najważniejsze prace opublikowane przez Tauska w ciągu czterech lat (1912-1916). Jest to duży dorobek, biorąc pod uwagę fakt, że jego autor spędził połowę tego okresu, czynnie służąc w armii podczas działań wojennych. W pracach tych można znaleźć wątki uzupełniające teorię psychoanalizy, będącą podówczas in statu nascendi (na przykład sugestie na temat genezy zapominania), jak i nowatorskie, z punktu widzenia zastanej wiedzy, poglądy na temat przyczyn schizofrenii. Tausk nie wahał się sięgać do swoich doświadczeń i obserwacji osób najbliższych (jeden $\mathrm{z}$ artykułów dotyczył marzeń sennych jego małoletnich synów), można więc sądzić, że mocno przeżywał problemy środowiska psychoanalityków, $\mathrm{w}$ którym zapewne pragnął być osobą znaczącą. Wypada dodać, że zarówno podejmowane przez niego tematy, jak i kierunki ich analizy bywały polemiczne w stosunku do poglądów Freuda. Dzięki darowi obserwacji i samodzielności myślenia Tausk miał szansę uwolnić się spod wpływów Freuda i podążyć własną drogą, tak jak uczynili to (z zyskiem dla siebie i dla nauki) choćby Alfred Adler i Carl Gustav Jung, jednak z powodów znanych wyłącznie sobie nie uczynił tego.

Nie ulega wątpliwości, że Viktor Tausk był człowiekiem o osobowości emocjonalnie skomplikowanej. W swoim studium o dezerterach pisał, że zabrał się za nie z wielką awersją. Zbyt trudnym moralnie był dla niego aspekt prawny samowolnego opuszczenia oddziału w czasach, gdy inni ginęli na froncie. Nie wszyscy dostrzegają i należycie oceniają jego wkład w rozwój psychoanalizy oraz psychiatrii. W obszernym studium o wpływie działań wojennych na psychikę żołnierzy Ben Shepard (2000) pominął nazwisko Tauska, chociaż wiele miejsca poświęcił I wojnie światowej i często powołuje się na poglądy Freuda. Tak samo zresztą potraktował Teodora Reika (1888-1969), który również, po tym, jak został zmobilizowany podczas I wojny światowej, w rezultacie obserwacji poczynionych na froncie (jako oficer kawalerii) zajął się stresem pourazowym (Mühlleitner, 1992).

Postać Viktora Tauska, przedwcześnie zmarłego psychoanalityka, bardziej intryguje literatów niż psychologów i historyków nauki. Skomplikowane relacje między Tauskiem, Freudem a Lou Andreas-Salomé ${ }^{12}$ posłużyły za kanwę dramatu Roberta Langsa (2000). Związki te zafascynowały również Brendę Webster, autorkę powieści Vienna Triangle, wydanej w tym samym roku (2009), w którym Sibila Petlevski poświęciła Tauskowi tom swojej trylogii Tabu (Petlevski, 2009). Być może prawie dwuletni romans z Lou Andreas-Salomé, która pojawiła się w Wiedniu przed pierwszą wojną, aby poznawać tajemnice psychoanalizy, miały

12 Relacje te zostały udokumentowane i obszernie przedstawione m. in. w pracy Rudolpha Biniona (1968). 
wpływ na to, że gdy Tausk po powrocie do „cywila” zdecydował się rozpocząć praktykę psychoanalityczną, Freud odesłał go na sesje do Heleny Deutsch (Roazen, 1985). Jednak wkrótce twórca psychoanalizy zażądał od Deutsch, aby przerwała te spotkania, co przyczyniło się do pogłębienia kryzysu psychicznego u Tauska. Po jego samobójczej śmierci Freud rozpowszechniał teorię, że każdy, kto odbiera sobie życie, pragnie najpierw bezskutecznie zabić kogoś innego. W tym przypadku Freud uważał, że on sam był celem nieskutecznych zbrodniczych planów Viktora Tauska (Roazen, 1973). Wydaje się jednak, że dłuższy i głębszy związek Tauska z ruchem psychoanalitycznym był od samego początku skazany na niepowodzenie ze względu na jego cechy osobowości i ambicje, które były trudne do zaspokojenia. Jego drażliwość i konfliktowość dały się we znaki innym uczestnikom środowych posiedzeń niemal od pierwszego spotkania. Wilhelm Stekel przytoczył jeden z takich przykładów:

Wśród nowych członków był bardzo utalentowanym lekarz nazwiskiem Tausk, były sędzia, który z nieznanych powodów był szczególnie krytyczny w stosunku do mnie. Każdy nowy członek klubu musiał wygłosić referat wstępny. Tausk mówił na temat „filozofii i psychoanalizy”, obiecując zbudować most między filozofią i Freudem. Wykład swój zaczął znakomicie, ale w środku przemowy utknął zdezorientowany i nie był w stanie go dokończyć. Był to niekomfortowy moment dla nas wszystkich. Próbowałem ratować sytuację i spontanicznie kontynuowałem ten wykład. [Tausk] prawdopodobnie nigdy nie wybaczył mi tego; przy najbliższej okazji, potępił moją nową książkę i obszernie omówił błędy gramatyczne $w$ jej przedmowie. (Gutheil, 1950, s. 132-133; tłum. C.D.)

Doświadczenia wojenne zapewne te cechy pogłębiły. Wyznaczona na superwizorkę Tauska Helena Deutsch pisała: „Freud bezsprzecznie miał pełne zaufanie do moich umiejętności. Dowodzi tego fakt, że jako pierwszego pacjenta przysłał do mnie członka własnej rodziny oraz że powierzył mi skomplikowany przypadek bardzo zaburzonego Victora Tauska" (2008, s. 154).

Być może tytuł niniejszych rozważań wydaje się paradoksalny, lecz zawarty w nim oksymoron został użyty celowo. Z punktu widzenia historii psychoanalizy kilkumiesięczny pobyt osoby z kręgu Sigmunda Freuda w Lublinie podczas I wojny światowej wydaje się biograficznym epizodem, lecz biorąc pod uwagę to, czym zaowocował on dla Viktora Tauska, był to w jego życiu okres pracowity i znaczący. Podjął on wówczas bardzo istotne problemy, z którymi na co dzień zmagano się na wszystkich frontach wojny. Względny spokój, który panował w mieście leżącym $\mathrm{z}$ dala od bezpośrednich działań wojennych, pozwalał na lepszy kontakt z pacjentami, a także dawał możliwość dokładniejszej ich obserwacji. Można by rzec, iż psychiatria i psychologia tamtego okresu została poddana trudnej próbie: wojna wyzwoliła niespotykane dotąd problemy, z którymi wypadało się mierzyć wielu lekarzom. Dezercja, zaburzenia psychiczne 
i symulacja stanowiły codzienność wojennej rzeczywistości. Nie bez powodu antologia prac Tauska nosi tytuł War and Schizophrenia, gdyż właśnie tropiąc destrukcyjne dla psychiki następstwa wojny, zapewnił sobie ważne miejsce w badaniach nad istotą psychoz wojennych.

\section{Bibliogr AFI A}

Aus dem Verordnungsblatt Nr. 119 für das k. u. k. Heer (1916, 9 lipca). Neue Freie Presse, 18635, 34.

Binion, R. (1968). Frau Lou: Nietzsche's Wayward Disciple. Princeton: Princeton University Press.

Brajša, P. (1981, 19 marca). Viktor Tausk - znamieniti Varaždinac. Varaždinske Vijesti, 1886, s. 8.

Bronner, A. (red.). (2008). Vienna Psychoanalytic Society. The First 100 Years. Wien: Christian Brandstätter Verlag.

Deutsch, H. (2008). Konfrontacje z sama sobą. Epilog. Warszawa: Wydawnictwo Cyklady.

Doliński, W. (1992). Przekażmy przeszłość dla przyszłości. Pamiętnik Wojciecha Dolińskiego. Hove: Caldra House.

Domański, C.W. (2009). Geniusz, który zawiódł. Charaktery, 2(145), 48-50.

Eissler, K.R. (1983). Victor Tausk's Suicide. New York: International Universities Press.

Jukić, T. (2011). Kritika i klinika: slučaj Viktora Tauska. W: C. Pavlović, V. Glunčić-Bužančić, A. Meyer-Fraatz (red.), Poetika i politika kulture nakon 1910. godine (s. 231-245). Split-Zagrzeb: Knjiga Mediterana.

Gutheil, E.A. (red.). (1950). The Autobiography of Wilhelm Stekel. The Life Story of a Pioneer Psychoanalyst. New York: Liverlight Publishing Corporation.

Konefał, J. (1999). Legiony Polskie w Lubelskiem 1914-1918. Lublin: Redakcja Wydawnictw Katolickiego Uniwersytetu Lubelskiego.

Langs, R. (2000). Freud's Bird of Prey: A Play in Two Acts. Phoenix: Zeig Tucker \& Theisen Inc.

Mühlleitner, E. (1992). Biographisches Lexikon der Psychoanalyse. Die Mitglieder der Psychologischen Mittwochgesellschaft und der Wiener psychoanalytischen Vereinigung 1902-1938. Tübingen: edition diskord.

Petlevski, S. (2009). Vrijeme laži - Tabu I. Zaprešić: Fraktura d. o. o.

Roazen, P. (1973). Brother Animal. The Story of Freud and Tausk. Harmondsworth: Penguin Books.

Roazen, P. (1985). Helene Deutsch. A Psychoanalyst's Life. Garden City: Anchor Press/Doubleday.

Roazen, P. (2001). The Historiography of Psychoanalysis. New Brunswick-London: Transaction Publishers. 
Shepard, B. (2000). A War of Nerves. Soldiers and Psychiatrists in the Twentieth Century. Cambridge: Harvard University Press.

Tausk, V. (1916/1991a). Diagnostic Considerations Concerning the Symptomatology of the So-Called War Psychoses. W: V. Tausk. Sexuality, War, and Schizophrenia. Collected Psychoanalytic Papers (s. 119-140). New Brunswick-London: Transactions Publishers.

Tausk, V. (1916/1991b). On the Psychology of the War Deserter. W: V. Tausk. Sexuality, War, and Schizophrenia. Collected Psychoanalytic Papers (s. 141165). New Brunswick-London: Transactions Publishers.

Tausk, V. (1991). Sexuality, War, and Schizophrenia. Collected Psychoanalytic Papers. New Brunswick-London: Transactions Publishers.

Tréhel, G. (2006). Victor Tausk (1879-1919) et la médecine militaire. L'Information psychiatrique, 82(3), 239-247.

Vereinsnachrichten (1915, 6 czerwca). Neue Freie Presse, 18244, 14.

Vjelković, S. (2012). Život i rad Vojne bolnice u Beogradu za vreme Velikog rata (1914-1918). Pobrane z: http://www.rastko.rs/rastko/delo/14674

Webster, B. (2009). Vienna Triangle. San Antonio: Wings Press.

Weiss, E. (1991). Sigmund Freud as a Consultant. Recollections of a Pioneer in Psychoanalysis. New Brunswick, NJ: Transaction Publishers. 